\title{
PENERAPAN REWARD AND PUNISHMENT DALAM MENINGKATKAN DISIPLIN GURU DI SMP NEGERI 1 PELEPAT ILIR
}

\author{
Dyah Ayu Sapto Rini \\ SMPN 1 Pelepat Ilir \\ Email: dyahayurini3@gmail.com
}

\begin{abstract}
Improving the quality of learning in school is very dependent on several factors. One of them, the improvement of good culture in schools. School culture is a positive thing that must be maintained and implemented by all school residents without feeling compelled. One of the culture of schools that must be maintained is the problem of discipline, including the discipline of the teachers in attending class in the teaching and learning process. As a figure who is always modeled after his behavior, the timely attendance of teachers in class is a clear example of discipline that will be seen and even emulated by students. This study aims to describe the improvement of teacher discipline in teaching presence in the classroom through the application of Reward and Punishment. This research is a case study using a qualitative approach. The research subjects were educators in SMPN 1 Pelepat Ilir. The method used in this study is the School Action Research (PTS) method. The results achieved from this study are that the application of Reward and Punishment is effective for increasing the discipline of teacher presence in class in teaching and learning activities.
\end{abstract}

Keywords: Teacher Discipline, Reward and Punishment

\begin{abstract}
Abstrak
Peningkatan mutu pembelajaran di sekolah sangat tergantung dari beberapa faktor. Salah satunya, peningkatan budaya baik di sekolah. Budaya sekolah merupakan hal yang positif yang harus dipertahankan dan dilaksanakan oleh semua warga sekolah tanpa merasa terpaksa. Budaya sekolah yang harus dipertahankan salah satunya adalah masalah kedisiplinan, termasuk disiplin para guru dalam kehadiran di kelas pada proses belajar mengajar. Sebagai figur yang senantiasa dicontoh perilakunya, kehadiran tepat waktu para guru di kelas merupakan contoh nyata kedisiplinan yang akan dilihat bahkan dicontoh oleh peserta didik. Penelitian ini bertujuan untuk mendeskripsikan peningkatan disiplin guru dalam kehadiran mengajar dikelas melalui penerapan Reward and Punishment. Penelitian ini merupakan studi kasus dengan menggunakan pendekatan kualitatif. Subjek penelitian adalah pendidik di lingkungan SMPN 1 Pelepat Ilir. Metode yang digunakan dalam penelitian ini adalah metode Penelitian Tindakan Sekolah (PTS). Hasil yang dicapai dari penelitian ini adalah
\end{abstract}

Nur El-Islam, Volume 7, Nomor 2, Oktober 2020 
bahwa penerapan Reward dan Punishment efektif untuk meningkatkan disiplin kehadiran guru dikelas pada kegiatan belajar mengajar.

Kata Kunci: Disiplin Guru, Reward and Punishment

\section{A. PENDAHULUAN}

1. Latar Belakang

Dalam rangka mewujudkan tujuan pendidikan nasional diperlukan profil kualifikasi seluruh warga sekolah. Salah satu komponen pendukung yang paling penting adalah guru. Guru adalah pendidik profesional yang mempunyai tugas, fungsi, dan peran penting dalam mencerdaskan kehidupan bangsa. Guru yang profesional diharapkan mampu berpartisipasi dalam pembangunan nasional untuk mewujudkan insan Indonesia yang bertakwa kepada Tuhan YME, unggul dalam ilmu pengetahuan dan teknologi, memiliki jiwa estetis, etis, berbudi pekerti luhur, dan berkepribadian.

Oleh sebab itu, profesi guru perlu dikembangkan secara terus menerus dan proporsional menurut jabatan fungsional guru. Sebagai figur yang senantiasa dicontoh perilakunya, guru haruslah mempunyai sikap disiplin dalam kerjanya, salah satunya adalah dalam proses belajar mengajar. Guru merupakan figur sentral karena di tangan gurulah terletak kemungkinan berhasil atau tidaknya pencapaian tujuan belajar mengajar di sekolah, dimana salah satu tujuan pembelajaran di kelas adalah pembentukan karakter disiplin pada siswa. Kehadiran tepat waktu para guru di kelas merupakan contoh nyata kedisiplinan yang akan dilihat bahkan dicontoh oleh peserta didik.

SMP Negeri 1 Pelepat Ilir yang berdiri pada tahun 1982 merupakan sekolah pertama di kecamatan Pelepat Ilir pada masa program transmigrasi di era kepemimpinan Presiden Soeharto. Sekolah ini pada awalnya bernama SMP Negeri 4 Pelepat. SMP Negeri 1 Pelepat Ilir menempati lahan seluas $8.370 \mathrm{~m}^{2}$ dengan luas bangunan sebanyak $4.828 \mathrm{~m}^{2}$, yang terletak di Desa Purwasari, Kecamatan Pelepat Ilir, yang berjarak kurang lebih $50 \mathrm{~km}$ dari Kota Kabupaten Bungo. SMP Negeri 1 Pelepat Ilir merupakan sekolah menengah yang cukup besar dengan 510 peserta didik yang terbagi 
dalam 18 rombel, 5 rombel untuk kelas VII, 6 rombel untuk kelas VIII, dan 5 rombel untuk kelas IX. Sekolah ini mempunyai 31 guru dimana terdapat 18 guru PNS dan 13 guru honor, dimana guru honor terdiri atas dua yaitu honor kontrak daerah dan honor komite ${ }^{1}$.

Seiring dengan perkembangan di dunia pendidikan, SMP Negeri 1 Pelepat Ilir menjelma menjadi salah satu sekolah dengan prestasi yang sangat membanggakan. Ketika penulis mendapat tugas untuk menjadi kepala sekolah di SMP Negeri 1 Pelepat Ilir di pertengahan bulan Juli tahun 2018, penulis menemukan fakta di lapangan bahwa kedisiplinan guru masih rendah, terutama masalah disiplin guru masuk kedalam kelas pada saat kegiatan pembelajaran di kelas. Hal ini mendorong semangat penulis untuk melakukan penelusuran melalui penelitian ilmiah guna memperbaiki berbagai kelemahan-kelemahan tersebut.

\section{Identifikasi Masalah}

Adapun yang menjadi identifikasi masalah dalam penelitian ini adalah rendahnya kedisipilinan para guru di SMP Negeri 1 Pelepat Ilir. Hal ini ditandai dari beberapa indikator disiplin diri guru, yaitu: ketepatan waktu dalam memulai pembelajaran yang tidak tepat waktu, kepatuhan terhadap atasan yang masih kurang, peraturan terhadap perilaku terlarang yang terkadang tidak diindahkan, ketertiban terhadap peraturan yang berhubungan langsung dengan produktivitas kerja yang masih lemah.

\section{Teori/Kajian}

\section{a. Disiplin Guru}

Keberhasilan siswa dalam pembelajaran serta peningkatan mutu sekolah tidak hanya menjadi tanggung jawab kepala sekolah saja, akan tetapi menjadi tanggung jawab bersama antara guru, orang tua, masyarakat serta pemerintah. Kinerja guru menjadi salah satu unsur dalam upaya peningkatan mutu sekolah. Kinerja guru meliputi kedisiplinan guru dan etos kerja. Apabila kedisiplinan telah menjadi

\footnotetext{
${ }^{1}$ Observasi Penulis di SMP 1 Negeri Pelepat Ilir, Tanggal 22 April 2020.
} 
budaya sekolah, maka arah pencapaian peningkatan mutu sekolah akan tercapai.

Perilaku disiplin harus dimiliki oleh semua orang, tidak terkecuali oleh seorang guru. Kedisiplinan pada guru dapat dijabarkan sebagai berikut:

Disiplin pada guru dimaksudkan bahwa guru harus mematuhi berbagai peraturan dan tata tertib secara konsisten, atas kesadaran professional, karena mereka bertugas untuk mendisiplinkan para peserta didik di sekolah terutama dalam pembelajaran. Oleh karena itu dalam menanamkan disiplin, guru harus memulai dari dirinya sendiri, dalam berbagai tindakan dan perilakunya ${ }^{2}$.

Berdasarkan pengertian Mulyasa di atas, yang dimaksud dengan kedisiplinan guru adalah guru yang mematuhi berbagai peraturan dan tata tertib yang berlaku, terutama dalam pembelajaran. Banyak para ahli yang memberikan batasan tentang pengertian kedisiplinan guru antara lain sebagai berikut: 1) Oteng Sutrisno berpendapat bahwa kedisiplinan guru adalah suatu keadaan tertib dan teratur yang dimiliki guru dalam sekolah tanpa ada pelanggaran-pelanggaran yang dapat merugikan baik secara langsung maupun tidak langsung terhadap dirinya, teman sejawatnya dan terhadap sekolah secara keseluruhan sehingga dapat membimbing kearah pertumbuhan kepribadian peserta didik secara sistematis dan pragmatis supaya mereka hidup sesuai dengan ajaran Islam sehingga terjalin kebahagiaan di dunia dan akhirat ${ }^{3}$. 2) Elizabeth. B. Hurlock memberikan pengertian kedisiplinan sebagai berikut: kedisiplinan merupakan sikap mental untuk melakukan halhal yang seharusnya pada saat yang tepat dan benar-benar menghargai waktu ${ }^{4}$.

${ }^{2}$ Mulyasa, Menjadi Guru Profesional, Menciptakan Pembelajaran Kreatif dan Menyenangkan. Bandung: PT Remaja Rosdakarya, 2006:37-38.

${ }^{3}$ Oteng Sutrisno, Administrasi Pendidikan Dasar Teoritis dan Praktek Professional, (Bandung:Angkasa,1985), h. 97

${ }^{4}$ Elizabeth.B.Hurlock, Psikologi Anak Jilid 2, (Jakarta: Erlangga, 1996), h.82. 
Sedangkan guru adalah pendidik professional dengan tugas utama mendidik dan mengevaluasi peserta didik, pada pendidikan anak usia dini jalur pendidikan formal, pendidikan dasar dan pendidikan menengah. Dalam informasi tentang wawasan wiyatamandala, kedisiplinan guru diartikan sebagai sikap mental yang mengandung kerelaan, peraturan dan norma yang berlaku dalam menunaikan tugas dan tanggung jawab ${ }^{5}$.

Dari pengertian diatas dapat disimpulkan kedisiplinan guru adalah sikap penuh kerelaan dalam mematuhi semua aturan dan norma yang ada dalam menjalankan tugasnya sebagai bentuk tanggung jawabnya terhadap pendidikan anak didiknya. Karena bagaimanapun seorang guru atau tenaga kependidikan (pegawai, merupakan cermin bagi anak didiknya dalam sikap atau teladan. Sikap disiplin dan tenaga kependidikan (pegawai) akan memberikan warna terhadap hasil pendidikan yangjauh lebih baik. Guru dan kedisiplinan menjadi dua sisi mata koin yang tidak dapat dipisahkan. Tanpa kedisiplinan dalam melaksanakan tugas profesinya, maka tujuan mulia dari proses pembelajaran tidak akan pernah tercapai. Sesuai dengan perintah Allah dalam Al-Qur'an Surat An-Nisa' ayat 59 di bawah ini:

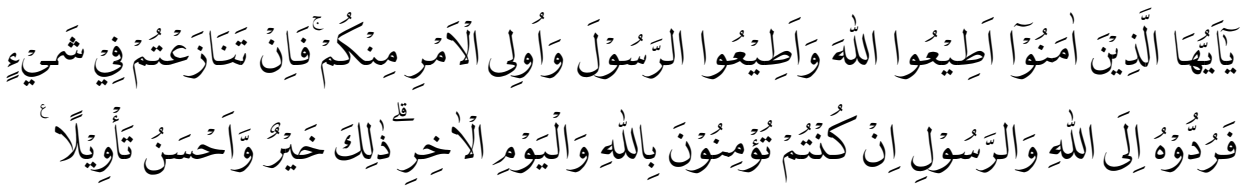

Artinya: Wahai orang-orang yang beriman! Taatilah Allah dan taatilah Rasul (Muhammad), dan Ulil Amri (pemegang kekuasaan) di antara kamu. Kemudian, jika kamu berbeda pendapat tentang sesuatu, maka kembalikanlah kepada Allah (Al-Qur'an) dan Rasul (sunnahnya), jika kamu beriman kepada Allah dan hari kemudian.

${ }^{5}$ Agus Wibowo, Pendidikan Karakter, Strategi membagun Karakter Bangsa Berperadapan, (Jogjakarta: Pustaka Pelajar, 2012), h. 85-86. 
Yang demikian itu lebih utama (bagimu) dan lebih baik akibatnya ${ }^{6}$.

Berdasarkan ayat di atas, terlihat bahwa disiplin pada hakikatnya adalah kemampuan untuk mengendalikan diri dalam bentuk tidak melakukan sesuatu tindakan yang tidak sesuai dan bertentangan dengan sesuatu yang telah ditetapkan dan melakukan sesuatu yang mendukung dan melindungi sesuatu yang telah ditetapkan. Disiplin kerja adalah persepsi guru terhadap sikap pribadi guru dalam hal ketertiban dan keteraturan diri yang dimiliki oleh guru dalam bekerja di sekolah tanpa ada pelanggaran- pelanggaran yang merugikan dirinya, orang lain, atau lingkungannya. Melalui disiplin pula timbul keinginan dan kesadaran untuk menaati peraturan organisasi dan norma sosial. Namun tetap pengawasan terhadap pelaksanaan disiplin tersebut perlu dilakukan.

Penerapan budaya sekolah termasuk penerapan disiplin semua warga sekolah dapat terwujud apabila semua warga sekolah mempunyai komitmen yang kuat untuk mewujudkannya. Penerapan disiplin warga sekolah, khususnya disiplin guru dalam melaksanakan proses belajar mengajar sangat berkait kepada kinerja guru itu sendiri. Apabila disiplin guru telah dilaksanakan dengan baik dan kinerja guru juga baik, serta didukung oleh faktor-faktor lain yang mendukung maka akan tercipta kondisi sekolah yang kondusif yang pada akhirnya tujuan sekolah untuk menjadi sekolah yang bermutu akan dapat tercapai. Kepala sekolah selaku pemimpin pembelajaran mempunyai peran yang sangat strategis dalam upaya pengembangan budaya sekolah. Kepala sekolah selaku pemimpin pembelajaran harus bisa memberikan contoh kepada semua warga sekolah agar tercipta budaya disiplin di sekolah, yang pada akhirnya akan meningkatkan mutu sekolah. 128.

${ }^{6}$ Departemen Agama, Al-Qur'an dan Terjemahannya, (SuratAn-Nisa'Ayat:59), h. 


\section{b. Reward and Punishment}

Salah satu metode penerapan disiplin melalui pemberian reward and punishment. Reward dan punishment dikembangkan dari suatu konsep manajemen sumber daya manusia, terutama ditujukan dalam memotivasi seseorang melakukan kebaikan dan meningkatkan prestasinya. Kedua metode ini sudah cukup lama dikenal dalam dunia pendidikan. Tidak hanya dalam dunia pendidikan, bahkan dalam dunia kerjapun kedua metode ini kerap kali digunakan ${ }^{7}$. Secara bahasa reward berasal dari bahasa Inggris yang diartikan sebagai ganjaran, hadiah, upah dan penghargaan ${ }^{8}$. Reward adalah situasi atau pernyataan lisan yang bisa menghasilkan kepuasan atau menambah kemungkinan suatu perbuatan yang dikerjakan ${ }^{9}$. Dalam bahasa Arab padanan kata reward adalah targhib.Targhib adalah suatu motivasi untuk mencapai tujuan keberhasilan mencapai tujuan yang memuaskan motivasinya dianggap sebagai ganjaran atau balasan yang menimbulkan perasaan senang ${ }^{10}$. Al-Nahlawi mendefinisikan targhib sebagai janji yang disertai dengan bujukan dan rayuan untuk menunda kemaslahatan, kelezatan, kenikmatan, namun penundaan itu bersifat pasti baik dan murni, serta dilakukan melalui amal shaleh atau pencegahan diri dari kelezatan yang membahayakan (pekerjaan buruk) ${ }^{11}$.Targhib juga diartikan, tanda jasa, penghargaan, hadiah, imbalan dan ganjaran ${ }^{12}$. Ngalim Purwanto mendefinisikan bahwa reward (ganjaran) ialah alat untuk

${ }^{7}$ Anwar Prabu Mangkunegara, Manajemen Sumber Daya Manusia Perusahaan (Bandung: Remaja Rosdakarya, 2000), h. 47.

${ }^{8}$ John, M. Echols dan Hasan Sadily, Kamus Inggris-Indonesia (Jakarta: Gramedia, 2003), h. 135.

${ }^{9}$ C.P. Caplin, Kamus Lengkap Psikologi, Terj.Kartini Kartono (Jakarta: Rajawali, 1989), h. 436.

${ }^{10}$ Muhammad Usman Najati, Psikologi Dalam Al-Quran,Terj. M. Zaka Al-Farisi (Bandung:Pustaka Setia, 2005), h. 265.

${ }^{11}$ Abdurrahman An-Nahlawi, Pendidikan Islam Dirumah, Sekolah dan Masyarakat,Terj.Shihabuddin (Jakarta: Gema Insane Press, 1995), h. 295.

${ }^{12}$ Peter Salim, Advenced English Indonesia Dictionary (Jakarta: Modern English Press, 1991) h.,719. 
mendidik anak-anak supaya anak dapat merasa senang karena perbuatan atau pekerjaannya mendapat penghargaan ${ }^{13}$.

Sedangkan menurut Roestiyah N.K. reward (penghargaan) merupakan perbuatan yang bernilai positif dengan memberi dorongan pada anak (peserta didik), sehingga anak bersedia untuk berbuat sesuatu ${ }^{14}$. Dari beberapa pendapat di atas, dapat disimpulkan bahwa reward (ganjaran) adalah segala sesuatu yang berupa penghargaan yang menyenangkan perasaan yang diberikan kepada siswa karena mendapat hasil baik dalam proses pendidikannya dengan tujuan agar senantiasa melakukan pekerjaan yang baik dan terpuji ${ }^{15}$. Reward (ganjaran) merupakan alat pendidikan yang mudah dilaksanakan dan sangat menyenangkan para guru dan siswa, untuk itu reward (ganjaran) dalam suatu proses pendidikan sangat dibutuhkan keberadaannya demi meningkatkan motivasi berdisiplin dan prestasi guru. Reward artinya ganjaran, hadiah, penghargaan atau imbalan. Dalam konsep manajemen, reward merupakan salah satu alat untuk peningkatan motivasi para pegawai. Metode ini bisa mengasosiasikan perbuatan dan kelakuan seseorang dengan perasaan bahagia, senang, dan biasanya akan membuat mereka melakukan suatu perbuatan yang baik secara berulang-ulang. Selain motivasi, reward juga bertujuan agar seseorang menjadi giat lagi usahanya untuk memperbaiki atau meningkatkan prestasi yang telah dapat dicapainya

Hukuman menurut bahasa berasal dari bahasa Inggris, yaitu dari kata punishment yang berarti Law (hukuman) atau siksaan ${ }^{16 "}$. Dalam Kamus Lengkap Bahasa Indonesia, hukuman memiliki arti peraturan resmi yang menjadi pengatur. Menurut $M$. Ngalim Purwanto, punishment (hukuman) adalah penderitaan yang

${ }^{13}$ M. Ngalim Purwanto, Ilmu Pendidikan Teoretisdan Praktis (Bandung: Remaja Rosdakarya,2006), h. 182.

${ }^{14}$ Roestiyah N.K., Didaktik/Metodik (Jakarta: Bina Aksara, 1986), h. 62.

${ }^{15}$ Raihan, Penerapan Reward dan Punishment dalam Peningkatan Prestasi Belajar Pendidikan Agama Islam Terhadap Siswa SMA di Kabupaten Pidie, dalam DAYAH: Journal of Islamic Education Vol.2, No.1, 2019,h.115-130.

${ }^{16}$ John M. Echole dan Hasan Shadily, Kamus Inggris..., h. 456. 
diberikan atau ditimbulkan dengan sengaja oleh seseorang (orang tua, guru, dan sebagainya) sesudah terjadi suatu pelanggaran, kejahatan atau kesalahan ${ }^{17}$. Adapun menurut Roestiyah, punishment (hukuman) adalah suatu perbuatan yang tidak menyenangkan dari orang yang lebih tinggi kedudukannya untuk pelanggaran dan kejahatan, yang bermaksud untuk memperbaiki kesalahan dan bukan untuk mendendam ${ }^{18}$. Punishment diartikan sebagai hukuman atau sanksi. Jika reward merupakan bentuk reinforcement yang positif, maka punishment sebagai bentuk reinforcement yang negatif, tetapi kalau diberikan secara tepat dan bijak bisa menjadi alat motivasi.

Beberapa penelitian terdahulu telah banyak mengkaji mengenai peranan metode reward and punishment ini terhadap kedisiplinan guru, beberapa diantaranya adalah: (1) Ruminis Siahaan dalam penelitiannya berjudul "Pengaruh Reward and Punishment Terhadap Disiplin Kerja Karyawan Pada PT. Perkebunan Nusantara III Rambutan” pada tahun $2013^{19}$. Persamaan Ruminis Siahaan dengan penulis terletak pada variabel (X1) Reward dan variabel (X2) Punishment. Dan yang membedakan penelitian terletak pada variabel (Y) dan objek penelitian, variabel (Y) dalam penelitian Ruminis Siahaan adalah Disiplin Kerja Karyawan, sedangkan variabel (Y) dalam penelitian penulis adalah kedisiplinan guru. Hasil penelitian dari Ruminis Siahaan menunjukan bahwa secara bersama- sama Reward dan punishment mempunyai pengaruh yang signifikan terhadap Disiplin Kerja. Reward dan punishment dapat merangsang kedisiplinan kerja karyawan. Melalui Reward dan punishment, karyawan merasa dapat perhatian, bimbingan, petunjuk, pengarahan dari atasannya, sehingga dengan sendirinya karyawan berusaha untuk memberikan yang terbaik kepada perusahaan tempatnya

${ }^{17}$ M. Ngalim Purwanto, Ilmu Pendidikan...,h. 186.

${ }^{18}$ Ny.Roestiyah N.K., Didaktik/Metodik.., h. 63.

${ }^{19}$ Rumiris Siahaan, Pengaruh Reward Dan Punishment Terhadap Disiplin Kerja Karyawan Pada Pt. Perkebunan Nusantara Iii Rambutan dalam Jurnal Ilmiah Bussiness Progress (Oktober 2013, Volume 1, NO.01, 17) 
bekerja. (2) Novita Dwi Jayanti dengan peneltiannya berjudul "Peran reward and Punishment Dalam Rangka Peningkatan Produktivitas Kerja Pegawai Pada Bank (Studi Pada PT. Bank Rakyat Indonesia Cabang Malang)" pada tahun 2014. Persamaan dalam penelitian yang dilakukan oleh Novita Dwi Jayanti dengan penulis terletak pada variabel (X1) Reward dan variabel (X2) Punishment. Dan yang membedakan penelitian terletak pada variabel (Y) dan objek penelitian, variabel (Y) dalam penelitian Novita Dwi Jayanti adalah Produktivitas Kerja Pegawai, sedangkan variabel (Y) dalam penelitian saya adalah Kinerja Karyawan. Hasil penelitian dari Novita Dwi Jayanti menujukan bahwa reward and punishment sama-sama berpengaruh dalam meningkatkan produktivitas kerja pegawai. Namun dalam hal ini, pemberia reward dirasa lebih berpengaruh dan lebih efektif dibandingkan punishment. Peran reward dalam bentuk promosi jabatanlah yang besar pengaruhnya terhadap produktivitas kerja pegawai ${ }^{20}$.

Peran reward dan punishment bagi SDM inipun juga harus dibawa menjadi bentuk participative. Dalam salah satu sistem manajemen participative ini mengakui dan berusaha memenuhi kebutuhan-kebutuhan manusiawi para pekerja. Tidak saja kebutuhan faali, tetapi juga kebutuhan-kebutuhan lainnya. Motivasi kerja tidak saja ditimbulkan melalui hadiah- hadiah ekonomis, tetapi juga melalui partisipasi dalam kelompok dan keterlibatannya dalam menentukan tujuan-tujuan pekerjaannya. Sikap kooperatif dan tenggang rasa (favorable) terhadap para tenaga kerja lainnya dalam organisasi. Bentuk partisipasi pengambilan keputusan dilakukan meluas dalam organisasi. Namun terintegrasi dengan baik. Dalam sistem manajemen ini dapat dikatakan tidak dirasakan adanya hubungan ketergantungan yang tidak seimbang dari bawahan terhadap atasan. Penerapan lain juga bisa diterapkan bagi karyawan atau aparatur meningkatkan disiplin SDM aparatur yang masih

${ }^{20}$ Ruminis Siahaan, Pengaruh Reward dan Punishment Terhadap Disiplin Kerja Karyawan Pada PT. Perkebunan Nusantara III Rambutan, dalam Jurnal Ilmiah vol. 1, 2013), h. 17. 
rendah dengan perubahan perilaku yang mendasar. Hal itu terjadi melalui revitalisasi pembinaan kepegawaian dan proses pembelajaran dengan membangun komitmen kuat dalam mengemban tugas sebagai pegawai negeri sipil, disertai pengembangan sistem reward dan punishment yang tepat dan efektif. Pemberian rewards and punishments sangat berkaitan dengan terlaksananya kedisiplinan guru dalam kegiatan belajar mengajar di kelas.

\section{Tujuan Penulisan}

Penelitian ini bertujuan untuk: a). Untuk menganalisis pengaruh reward terhadap disiplin kerja guru SMP Negeri 1 Pelepat Ilir. b). Untuk menganalisis pengaruh punishment terhadap disiplin kerja guru SMP Negeri 1 Pelepat Ilir. c) Untuk menganalisis pengaruh reward dan punishment terhadap disiplin kerja guru SMP Negeri 1 Pelepat Ilir.

\section{B. Metodologi}

1. Metodologi Penelitian

Metode yang digunakan dalam penelitian ini adalah metode Penelitian Tindakan Sekolah (PTS). PTS merupakan suatu prosedur penelitian yang diadaptasi dari Penelitian Tindakan Kelas (PTK). Penelitian Tindakan Kelas sebagai sebuah proses investigasi terkendali yang berdaur ulang dan bersifat reflektif mandiri yang dilakukan oleh guru yang memiliki tujuan untuk melakukan perbaikan terhadap sistem, cara kerja, proses, isi, kompetensi atau situasi pembelajaran ${ }^{21}$. Penelitian Tindakan Sekolah merupakan "(1) penelitian partisipatoris yang menekankan pada tindakan dan refleksi berdasarkan pertimbangan rasional dan logis untuk melakukan perbaikan terhadap suatu kondisi nyata; (2) memperdalam pemahaman terhadap tindakan yang dilakukan; dan

${ }^{21}$ Susilo, Herawati dkk. Penelitian Tindakan Kelas, Sebagai Sarana Pengembangan Keprofesian Berkelanjutan Guru dan Calon Guru. (Malang: Bayu Media Publishing, 2009). 
(3) memperbaiki situasi dan kondisi sekolah / pembelajaran secara praktis $^{22}$.

Secara singkat, PTS bertujuan untuk mencari pemecahan permasalahan nyata yang terjadi di sekolah-sekolah, sekaligus mencari jawaban ilmiah bagaimana masalah-masalah tersebut bisa dipecahkan melalui suatu tindakan perbaikan. Permasalahan ini ditindaklanjuti dengan cara menerapkan sebuah model pembinaan kepada guru berupa penerapan Reward dan Punishment yang dilakukan oleh kepala sekolah, kegiatan tersebut diamati kemudian dianalisis dan direfleksi. Hasil revisi kemudian diterapkan kembali pada siklus-siklus berikutnya. Penelitian ini adalah penelitian tindakan model Stephen Kemmis dan Mc. Taggart (1998) yang diadaptasikan dalam penelitian ini. Model ini menggunakan sistem spiral refleksi diri yang dimulai dari rencana, tindakan, pengamatan, refleksi, dan perencanaan kembali yang merupakan dasar untuk suatu ancang-ancang pemecahan masalah. Penulis menggunakan model ini karena dianggap paling praktis dan aktual.

Penelitian ini dilaksanakan di SMPN 1 Pelepat Ilir Kabupaten Bungo dalam kurun waktu 3 bulan. Adapun yang menjadi subjek penelitian tindakan sekolah ini adalah guru-guru di SMP Negeri 1 Pelepat Ilir, Kabupaten Bungo, sejumlah 30 orang guru, terdiri atas 17 orang guru PNS, dan 13 orang guru Non PNS. Teknik pengumpulan data dari penelitian tindakan sekolah ini adalah melalui data kualitatif yang diperoleh dari observasi dan pengamatan. Analisa data yang digunakan dalam penelitian ini adalah analisa data kualitatif yang bersumber dari data primer maupun empiris. Melalui analisa data ini, dapat diketahui ada tidaknya peningkatan kedisiplinan guru dalam kehadiran dikelas melalui pemberian reward dan punishment yang merupakan fokus dari penelitian tindakan sekolah ini.

${ }^{22}$ UU Republik Indonesia No. 20 Tahun 2003. Sistem Pendidikan Nasional. (Jakarta: Depdiknas. 2003). 


\section{Hipotesis Penelitian}

Adapun yang menjadi hipotesis dalam penelitian ini adalah bahwa metode reward and punishment efektif dalam meningkatkan kinerja disiplin guru-guru SMP Negeri 1 Pelepat Ilir Kabupaten Bungo.

\section{Pembahasan}

1. Temuan Penelitian

a. Kegiatan Pra Siklus

Penelitian ini didahului dengan kegiatan pra siklus, dimana peneliti berdiskusi dengan rekan Kepala Sekolah pada tanggal 3 November 2019, dalam kesempatan ini penulis mendapatkan saran untuk menerapkan sebuah metode pendisiplinan melalui reward and punishment. Setelah tahap pra siklus dilaksanakan untuk mengumpulkan data awal terhadap kedisiplinan kehadiran guru di kelas dan sebelum penerapkan metode reward and punishment. Hasil pengamatan pra siklus dijelaskan dalam tabel 4.1.

Tabel 4.1. Hasil pengamatan pra siklus

\begin{tabular}{|c|l|l|l|}
\hline No & Waktu Keterlambatan & Jumlah & Persentase \\
\hline 1 & Kurang dari 10 Menit & 10 & $32 \%$ \\
\hline 2 & $\begin{array}{l}\text { 10 Menit s.d. 15 } \\
\text { Menit }\end{array}$ & 4 & $13 \%$ \\
\hline 3 & Lebih dari 15 Menit & 3 & $9.7 \%$ \\
\hline
\end{tabular}

Penelitian Tindakan Sekolah dilaksanakan dalam dua siklus, selama satu minggu, yaitu pada tanggal 12 November sampai dengan 17 November 2018.

\section{1) Siklus 1}

Siklus 1 terdiri atas beberapa tahap,yaitu: (1) Perencanaan, (2) Pelaksanaan, (3) Pengamatan dan Evaluasi, dan (4) Refleksi.

(a) Perencanaan

Perencanaan adalah langkah awal yang dilakukan oleh penulis saat akan memulai tindakan. Agar perencanaan mudah dipahami dan dilaksanakan oleh penulis yang akan melakukan tindakan. 
(b) Pelaksanaan

Pelaksanaan penelitian tindakan sekolah ini dilaksanakan melalui beberapa kegiatan, antara lain:

(1) Menyebarkan lembar pengamatan kepada setiap Ketua Kelas atau Sekretaris kelas sebanyak 18 set, sesuai dengan banyaknya jumlah rombongan belajar di SMP Negeri 1 Pelepat Ilir sebanyak 18 rombongan belajar. Dalam lembar pengamatan itu, telah dibuat daftar guru yang mengajar dikelas itu setiap jam dan diberi kolom jam masuk kelas serta jam keluar kelas. Lembar pengamatan dapat dilihat pada lampiran.

(2) Setelah selesai jam pelajaran, dilakukan rekapitulasi dari hasil pengamatan, baik dari guru piket dari siswa maupun dari penulis.

(3) Kegiatan tersebut dilakukan terus setiap hari kepada setiap guru selama satu minggu (satu siklus).

(c) Pengamatan dan Evaluasi

Pengamatan atau observasi dilakukan oleh peneliti dengan menggunakan lembar observasi selama satu minggu (satu siklus), untuk semua guru yang berjumlah 31 orang. Selama pengamatan peneliti dibantu atau berkolaborasi dengan wakil Kepala Sekolah dan siswa. Peneliti juga melakukan penilaian dari hasil lembar observasi yang dibagikan kepada pengurus kelas untuk mengamati kehadiran guru di kelas. Pengamatan atau observasi dilakukan oleh peneliti dengan menggunakan lembar observasi selama satu minggu (satu siklus), untuk semua guru yang berjumlah 31 orang. Selama pengamatan peneliti dibantu atau berkolaborasi dengan wakil kepala sekolah dan siswa. Pengamatan oleh peneliti meliputi: (a) Kehadiran guru di kelas, (b) Tingkat keterlambatan guru masuk kelas dan (c) Waktu meninggalkan kelas setelah selesai pelajaran.

Dari hasil pengamatan serta rekap dari tingkat kehadiran guru di kelas pada proses belajar mengajar dapat dilihat pada tabel berikut: 
Tabel 4.2. Rekapitulasi Tingkat Keterlambatan Guru pada Kehadiran di Kelas Siklus I

\begin{tabular}{|c|l|c|c|}
\hline No & Waktu Keterlambatan & Jumlah & Persentase \\
\hline 1 & Kurang dari 10 Menit & 7 & $23 \%$ \\
\hline 2 & 10 s.d. 15 Menit & 5 & $16 \%$ \\
\hline 3 & Lebih dari 15 Menit & 4 & $13 \%$ \\
\hline
\end{tabular}

Dari hasil rekapitulasi tingkat keterlambatan guru dikelas pada proses pembelajaran diperoleh data, sebanyak 7 orang guru terlambat masuk kelas kurang dari 10 menit, 5 orang guru terlambat masuk kelas 10 menit sampai dengan 15 menit, dan 4 orang guru terlambat masuk kelas lebih dari 15 menit. Setelah selesai satu siklus maka diadakan refleksi mengenai kelemahan atau kekurangan dari pelaksanaan tindakan pada siklus pertama. Refleksi dilaksanakan bersama- sama kolaborator untuk menentukan tindakan perbaikan pada siklus berikutnya. Dari hasil refleksi dapat diambil suatu kesimpulan bahwa perlu penerapan Reward dan Punishment yang lebih tegas lagi daripada siklus pertama.

\section{2) Siklus 2}

Siklus 2 terdiri atas beberapa tahap, sama seperti siklus 1 yaitu:

(1) Perencanaan, (2) Pelaksanaan, (3) Pengamatan dan Evaluasi, dan (4) Refleksi. Adapun penjelasannya adalah sebagai berikut:

(a) Perencanaan

Dari hasil refleksi pada siklus pertama, peneliti merencanakan untuk melakukan tindakan Reward dan Punishment yang lebih tegas dibandingkan dengan siklus pertama. Peneliti merencanakan untuk membacakan hasil observasi mengenai tingkat keterlambatan guru masuk kelas dalam proses belajar mengajar, dengan cara menyebutkan nama-nama guru yang terlambat dalam acara sharing di hari Sabtu berikutnya. Hal ini terlebih dahulu disosialisasikan kepada semua guru pada saat refleksi siklus pertama. 


\section{(b) Pelaksanaan}

Pelaksanaan penelitian tindakan sekolah pada siklus yang kedua ini dilaksanakan melalui beberapa kegiatan, antara lain:

(1) Menyebarkan lembar pengamatan kepada setiap Ketua Kelas atau Sekretaris kelas sebanyak 18 set, sesuai dengan banyaknya jumlah rombongan belajar di SMP Negeri 1 Pelepat Ilir sebanyak 18 rombongan belajar. Dalam lembar pengamatan itu, telah dibuat daftar guru yang mengajar dikelas itu setiap jam dan diberi kolom jam masuk kelas serta jam keluar kelas. Lembar pengamatan dapat dilihat pada lampiran.

(2) Setelah selesai jam pelajaran, dilakukan rekapitulasi dari hasil pengamatan, baik dari peneliti maupun dari siswa. Kegiatan tersebut dilakukan terus setiap hari kepada setiap guru selama satu minggu (satu siklus) pada siklus kedua

\section{(c) Pengamatan dan Evaluasi}

Pengamatan atau observasi dilakukan oleh peneliti dengan menggunakan lembar observasi selama satu minggu (satu siklus), untuk semua guru yang berjumlah 31 orang. Selama pengamatan peneliti dibantu atau berkolaborasi dengan wakil kepala sekolah dan siswa. Pengamatan oleh peneliti meliputi: (1) Kehadiran guru dikelas, (2) Tingkat keterlambatan guru masuk kelas dan (3) Waktu meninggalkan kelas setelah selesai pelajaran. Peneliti juga melakukan penilaian dari hasil lembar observasi yang dibagikan kepada pengurus kelas untuk mengamati kehadiran guru dikelas. Dari hasil pengamatan serta rekap dari tingkat kehadiran guru di kelas pada proses belajar mengajar pada siklus kedua dapat dilihat pada tabel berikut:

Tabel 4.3. Rekapitulasi Tingkat Keterlambatan Guru pada Kehadiran di Kelas Siklus II

\begin{tabular}{|c|l|c|c|}
\hline No & Waktu Keterlambatan & Jumlah & Persentase \\
\hline 1 & Kurang dari 10 Menit & 3 & $9.6 \%$ \\
\hline 2 & 10 Menit s.d. 15 Menit & 2 & $6.4 \%$ \\
\hline
\end{tabular}




\section{Lebih dari 15 Menit}

Dari hasil rekapitulasi tingkat keterlambatan guru dikelas pada proses pembelajaran diperoleh data, sebanyak 3 orang guru terlambat masuk kelas kurang dari 10 menit, 2 orang guru terlambat masuk kelas 10 menit sampai dengan 15 menit, dan tidak ada satu orangpun guru yang terlambat masuk kelas lebih dari 15 menit. Setelah selesai pelaksanaan tindakan pada siklus kedua maka diadakan refleksi mengenai kelemahan atau kekurangan dari pelaksanaan tindakan pada siklus kedua tersebut. Dari hasil observasi dan data yang diperoleh, peneliti mengambil kesimpulan bahwa tindakan yang dilaksanakan pada siklus kedua dinyatakan berhasil, karena terdapat $88 \%$ guru yang tidak terlambat masuk kelas atau melebihi target yang telah ditentukan sebesar $85 \%$.

\section{Pembahasan}

Tindakan yang dilakukan selama dua siklus menunjukkan adanya peningkatan tingkat kedisiplinan guru SMP Negeri 1 Pelepat Ilir Kabupaten Bungo masuk kelas atau dalam menjalankan tugasnya. Kriteria yang digunakan dalam penelitian tindakan sekolah ini upaya yang dilakukan dalam meningkatkan disiplin guru adalah sebagai berikut: (a) sekolah memiliki sistem pengendalian ketertiban yang dikelola dengan baik, (b) adanya keteladanan disiplin dalam sikap dan prilaku dimulai dari pimpinan sekolah, (c) mewajibkan guru untuk mengisi agenda kelas dan mengisi buku absen yang diedarkan oleh petugas piket, (d) pada awal masuk sekolah kepala sekolah bersama guru membuat kesepakatan tentang aturan kedisiplinan, (e) memperkecil kesempatan guru untuk ijin meninggalkan kelas, dan (f) setiap rapat pembinaan diumumkan frekuensi pelanggaran terendah. Secara umum dari enam criteria yang disepakati menunjukkan tingkat ketatan yang meningkat dan sebaliknya tingkat pelanggaran semakin menurun. Berdasarkan analisis data, dari penelitian ini dapat ditarik kesimpulan bahwa penerapan 
Reward dan Punishment efektif untuk meningkatkan disiplin kehadiran guru di kelas pada kegiatan belajar mengajar. Data yang diperoleh menunjukan bahwa setelah diadakan penerapan tindakan berupa Reward dan Punishment, guru yang terlambat lebih dari 15 menit adalah 0, dan guru yang terlambat kurang dari10 menit sebanyak 5 orang guru. Penerapan Reward dan Punishment dapat meningkat disiplin guru hadir didalam kelas pada kegiatan belajar mengajar. Hal ini juga sebagaimana yang terdapat dalam penelitian Li'ah Haryati bahwa metode reward and punishment efektif dalam meningkatkan kinerja disiplin guru ${ }^{23}$.

\section{Penutup}

Berdasarkan analisis data tersebut, dapat ditarik kesimpulan bahwa penerapan Reward dan Punishment efektif untuk meningkatkan disiplin kehadiran guru dikelas pada kegiatan belajar mengajar. Pada kegiatan pra siklus diperoleh data sebanyak guru terlambat masuk kelas. Data yang diperoleh menunjukan bahwa setelah diadakan penerapan tindakan berupa Reward dan Punishment, guru yang terlambat lebih dari 15 menit adalah 0 , dan guru yang terlambat kurang dari 10 menit sebanyak 3 orang guru. Penerapan Reward dan Punishment dapat meningkatkan disiplin guru hadir didalam kelas pada kegiatan belajar mengajar di SMP Negeri 1 Pelepat Ilir. Karena adanya pengaruh positif Penerapan Reward dan Punishment terhadap disiplin guru hadir didalam kelas pada kegiatan belajar mengajar, maka melalui kesempatan ini penulis mengajukan beberapa saran: (1) Semua Kepada Kepala Sekolah disarankan melakukan Penerapan Reward dan Punishment untuk meningkatkan disiplin guru hadir didalam kelas pada kegiatan belajar mengajar disekolah. (2) Kepada semua guru dalam melaksanakan tugas untuk dapat meningkatkan disiplin dalam kehadiran dikelas sebagai bentuk pelayanan minimal kepada peserta didik di sekolah.

${ }^{23}$ Li'ah Haryati, Upaya Meningkatkan Disiplin Gurudalam Kehadiran Mengajar Dikelas melalui Penerapan “Reward And Punishment” Dalam Media didaktika, Vol. 2, No. 2,November2016, h. 192. 


\section{Daftar Pustaka}

Abdurrahman An-Nahlawi.. Pendidikan Islam Dirumah, Sekolah dan Masyarakat, Terj.Shihabuddin. Jakarta: Gema Insane Press. 1995.

Agus Wibowo. Pendidikan Karakter, Strategi membagun Karakter Bangsa Berperadapan, Jogjakarta: Pustaka Pelajar. 2012.

Anwar Prabu Mangkunegara. Manajemen Sumber Daya Manusia Perusahaan. Bandung: Remaja Rosdakarya. 2000.

C.P. Caplin. Kamus Lengkap Psikologi, Terj.Kartini Kartono. Jakarta: Rajawali. 1989.

Departemen Agama. Al-Qur'an dan Terjemahannya. SuratAnNisa'Ayat:59.

Elizabeth.B.Hurlock. Psikologi Anak Jilid 2. Jakarta: Erlangga, 1996.

John, M. Echols dan Hasan Sadily. Kamus Inggris-Indonesia. Jakarta: Gramedia. 2003.

Li'ah Haryati. Upaya Meningkatkan Disiplin Gurudalam Kehadiran Mengajar Dikelas melalui Penerapan“Reward And Punishment” Dalam Media didaktika, Vol. 2, No. 2,November2016.

M. Ngalim Purwanto. Ilmu Pendidikan Teoretisdan Praktis. Bandung: Remaja Rosdakarya. 2006.

Muhammad Usman Najati. Psikologi Dalam Al-Quran,Terj. M. Zaka AlFarisi Bandung: Pustaka Setia. 2005.

Mulyasa. Menjadi Guru Profesional, Menciptakan Pembelajaran Kreatif dan Menyenangkan. Bandung: PT Remaja Rosdakarya, 2006.

Oteng Sutrisno. Administrasi Pendidikan Dasar Teoritis dan Praktek Professional. Bandung: Angkasa, 1985.

Peter Salim. Advenced English Indonesia Dictionary. Jakarta: Modern English Press, 1991. 
Raihan. Penerapan Reward dan Punishment dalam Peningkatan Prestasi Belajar Pendidikan Agama Islam Terhadap Siswa SMA di Kabupaten Pidie. dalam DAYAH: Journal of Islamic Education Vol.2, No.1, 2019.

Roestiyah N.K. Didaktik/Metodik. Jakarta: Bina Aksara, 1986.

Rumiris Siahaan, Pengaruh Reward Dan Punishment Terhadap Disiplin Kerja Karyawan Pada Pt. Perkebunan Nusantara Iii Rambutan dalam Jurnal Ilmiah Bussiness Progress (Oktober 2013, Volume 1, NO.01, 17)

Susilo, Herawati dkk. Penelitian Tindakan Kelas, Sebagai Sarana Pengembangan Keprofesian Berkelanjutan Guru dan Calon Guru. Malang: Bayu Media Publishing. 2009.

UU Republik Indonesia No. 20 Tahun 2003. Sistem Pendidikan Nasional. (Jakarta: Depdiknas. 2003). 